\title{
振動流場における非対称没水構造物の 方向抵抗特性に関する実験的研究 AN EXPERIMENTAL STUDY ON DIRECTIONAL RESISTANCE PROPERTIES OF A SUBMERGED ASYMMETRICAL ROUGHNESS
}

\author{
押川英夫 1 - 小松利光 $2 \cdot$ 柴多哲郎 $3 \cdot$ 深田剛教 4 \\ Hideo OSHIKAWA, Toshimitsu KOMATSU, Tetsuro SHIBATA and Takenori FUKATA \\ 1 正会員 工修 九州大学大学院助手 工学研究院環境都市部門 (T 812-8581 福岡市東区箱崎 6-10-1) \\ 2 フェロー 工博 九州大学大学院教授 工学研究院環境都市部門 (同上) \\ 3 学生員 九州大学大学院 工学府海洋システム工学専攻 (同上) \\ 4 正会員 福岡市土木局（广 812-8620 福岡市中央区天神 1-8-1）
}

\begin{abstract}
Directional characteristics of hydrodynamic force on a submerged asymmetrical roughness (we call this roughness BaNK block) in oscillatory flows were experimentally investigated. In this study, a quarter sphere or a half cylinder is used as a BaNK block which is set on the bottom of channel with an angle of attack $\theta$ to an oscillating flow direction. It is found that residual hydrodynamic force on half cylinder is much larger than that on quarter sphere because the substantial length of quarter sphere is smaller than that of half cylinder. Furthermore, residual hydrodynamic force on BaNK blocks is almost constant with the change of $\theta$ when Keulegan-Carpenter number $\mathrm{KC}$ is small. However, in large $\mathrm{KC}$ number, the force on quarter sphere decreases with the increase of $\theta$ because residual lift force decreases in $\theta=50^{\circ} \sim 90^{\circ}$.
\end{abstract}

Key Words :residual hydrodynamic force, oscillatory flow, submerged asymmetrical roughness, Keulegan-Carpenter number

\section{1. 緒言}

全国に約 19000 haある砂浜は, 最近 15 年間でその約 $13 \%$ に当たる約 $2400 \mathrm{ha}$ が失われるなど，侵食被害が深 刻化している. 海岸侵食は陸域への波の侵入の增大, 臨海施設などの機能低下の要因となるほか, 貴重な国土 の縮小にもつながるため, 効果的な侵食防止対策・砂浜 の創成技術の開発が, 緊急を要する重要課題となってい る。

このような背景の下,著者らは波浪エネルギーを用いた 有効な海岸侵食防止技術であり,かつ積極的な砂浜の創 成技術であるBaNK(:Beach and Navigation Keeper)システ ムを提案している ${ }^{1), 22}$. 本技術は, 波浪によって生じる往復 流場に非対称形状を有する構造物 (BaNKブロック)を複 数個設置するだけで,海底付近に波の一周期平均的な一 方向流れを任意の方向に生成させ，底質移動の自在な制 御を可能とするものである.

前報2)では3次元波浪場に複数のBaNKブロックを波 の進行方向に対し $0^{\circ}, 30^{\circ}, 50^{\circ}$ 傾けて設置して流速 の空間分布を測定することで, BaNKシステムにおける 波浪残差流の生成·偏流効果を示した. 関連した研究と して,小松ら ${ }^{3)}$ は非対称形状を有する流況制御ブロック(ス
ケールは格段に小さいがBaNKブロックも同様な形状を想 定している)を流れに対して傾けて設置することによって， 定常流場における抵抗力を評価し,潮流をステップ関数的 な往復流場と仮定した場合には,流況制御ブロックを潮流 の主軸方向から傾けて設置することにより, 任意の方向に 残差抵抗力を生成できることを明らかにしている，BaNK システムも基本的には同じ原理に基づいているため,本手 法においても同様な効果が得られると期待される.しかし, 定常流場における残差抵抗力はいわゆる抗力のみに基づ いた力であり,本システムが対象とする周期の短い波浪場 においては慣性力の寄与も大きいことが予想される.さら に浅海波浪場は非線型効果による波形の変形も生じるた め,定常流場における残差抵抗特性がそのまま波浪場に も適用できるかどうかは明らかではない.そこで本研究で は,任意の方向に任意の大きさで波浪残差流を生成可 能とするため, 詳細な室内実験により, 波浪残差流の driving force となるBaNKブロック単体に作用する 流体力の方向特性について検討した. なお, 構造物の 非対称性による効果のみを評価するため, 本実験では 往復流場として正弦波を発生させ易いピストン式の振 動流場を採用している. 

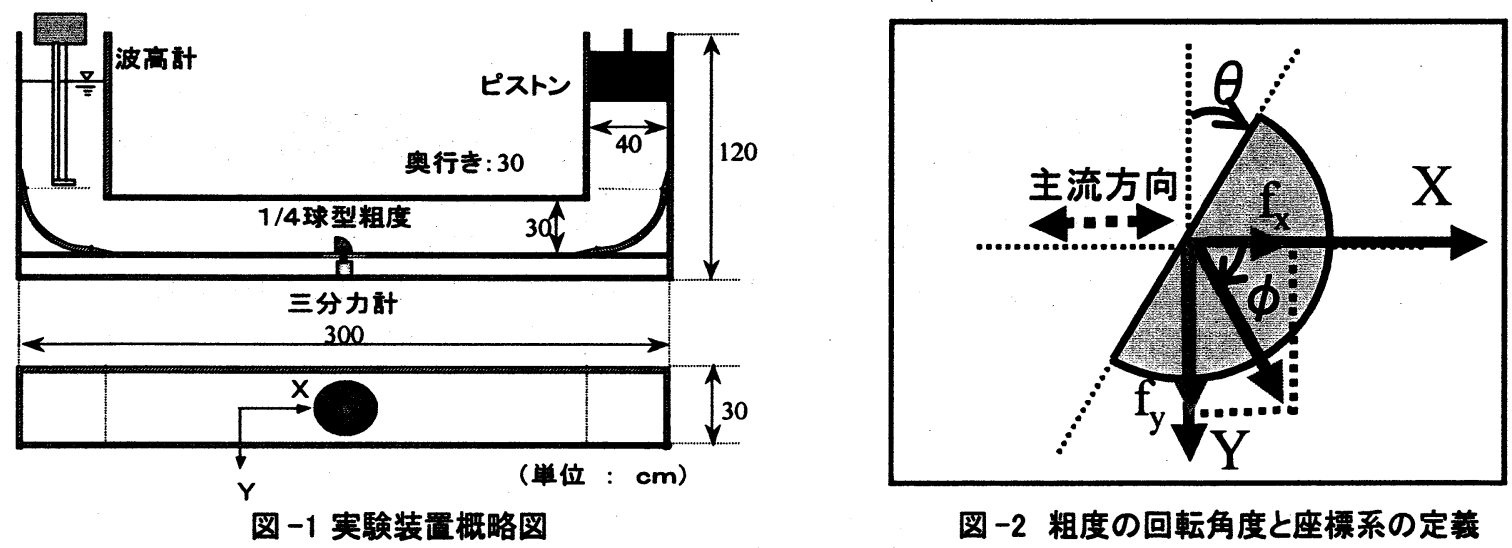

図 -2 粗度の回転角度と座標系の定義

表- 1 実験条件 (实験 I)

\begin{tabular}{|c|c|c|c|c|c|c|}
\hline 实洕 I & c.esoo-1 & $\cos 00-2$ & caso $0-3$ & c.aseo-4 & casoo- 0 & case. $0-6$ \\
\hline ブロック直怪 $\mathrm{D}(\mathrm{cm})$ & 10.0 & 10.0 & 10.0 & 10.0 & 10.0 & 10.0 \\
\hline 振 $\mathrm{a}(\mathrm{cm})$ & 12.0 & 10.0 & 6.0 & 12.0 & 10.0 & 6.0 \\
\hline 周期T(s) & 3.7 & 3.1 & 1.8 & 3.7 & 3.1 & 1.8 \\
\hline$R \in$ 数 & $2.7 \times 10^{4}$ & $2.7 \times 10^{4}$ & $2.7 \times 10^{4}$ & $2.7 \times 10^{4}$ & $2.7 \times 10^{4}$ & $2.7 \times 10^{4}$ \\
\hline $\mathrm{KC}$ 数 & 10.1 & 8.4 & 5.0 & 10.1 & 8.4 & 5.0 \\
\hline 粗度形状 & 半球 & 半球 & 半球 & 1/4 球 & $1 / 4$ 球 & $1 / 4$ 球 \\
\hline
\end{tabular}

表-2 実験条件 (実験 II)

\begin{tabular}{|c|c|c|c|c|c|c|c|c|c|c|}
\hline 实匼 II & casel & case 2 & cases 3 & case 4 & case 5 & case 6 & case? & case. 8 & case 9 & case 10 \\
\hline ブロック座缩 D $(\mathrm{cm})$ & 7.0 & 12.0 & 12.0 & 12.0 & 12.0 & 12.0 & 12.0 & 12.0 & 12.0 & 12.0 \\
\hline 握蜢 $\mathrm{a}(\mathrm{cm})$ & 13.3 & 16.0 & 10.7 & 6.7 & 21.3 & 21.3 & 16.0 & 10.7 & 21.3 & 16.0 \\
\hline 周期T(s) & 2.4 & 5.0 & 3.3 & 2.1 & 6.7 & 6.0 & 4.4 & 3.0 & 5.3 & 4.0 \\
\hline$R e$ 数 & $2.4 \times 10^{4}$ & $2.4 \times 10^{4}$ & $2.4 \times 10^{4}$ & $2.4 \times 10^{4}$ & $2.4 \times 10^{4}$ & $2.7 \times 10^{4}$ & $2.7 \times 10^{4}$ & $2.7 \times 10^{4}$ & $3.0 \times 10^{4}$ & $3.0 \times 10^{4}$ \\
\hline KC数 & 12.0 & 8.4 & 5.6 & 3.5 & 11.2 & 11.2 & 8.4 & 5.6 & 11.2 & 8.4 \\
\hline 粗度形状 & $1 / 4$ 球 & 1/4球 & $1 / 4$ 球 & $1 / 4$ 球 & 1/4球 & 1/4球 & $1 / 4$ 球 & $1 / 4$ 球 & $1 / 4$ 球 & $1 / 4$ 球 \\
\hline 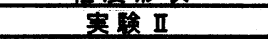 & casel1 & casel12 & cossel 3 & casel 4 & casiels & case 16 & caser 2 & coselis & cosselg & $\operatorname{cose} 20$ \\
\hline ブロック直经D(cm) & 12.0 & 12.0 & 7.0 & 10.0 & 7.0 & 10.0 & 10.0 & 12.0 & 10.0 & 12.0 \\
\hline 摄福 $\mathrm{a}(\mathrm{cm})$ & 10.7 & 16.0 & 8.3 & 6.0 & 13.4 & 16.0 & 11.9 & 7.2 & 9.0 & 14.3 \\
\hline 周朝T(s) & 2.7 & 3.0 & 4.2 & 3.0 & 3.0 & 5.4 & 4.0 & 2.9 & 3.0 & 4.8 \\
\hline Re数 & $3.0 \times 10^{4}$ & $4.0 \times 10^{4}$ & $1.65 \times 10^{4}$ & $1.65 \times 10^{4}$ & $2.5 \times 10^{4}$ & $2.5 \times 10^{4}$ & $2.5 \times 10^{4}$ & $2.5 \times 10^{4}$ & $2.5 \times 10^{4}$ & $3.0 \times 10^{4}$ \\
\hline KC 数 & 5.6 & 8.4 & 10.0 & 5.0 & 15.5 & 13.3 & 10.0 & 5.0 & 7.5 & 10.0 \\
\hline 粗度形状 & $1 / 4$ 球 & 1/4球 & 半月简 & 半用简 & 半用简 & 半用简 & 半口简 & 半円简 & 半丹管 & 半月简 \\
\hline
\end{tabular}

\section{2. 実験装置および方法}

実験は図-1に示すピストン駆動式U字管振動流装置(高 さ $120 \mathrm{~cm} \times$ 長さ $300 \mathrm{~cm} \times$ 奥行き $30 \mathrm{~cm})$ を用いた．小型三 分力計を取り付けた粗度を水槽の中央に設置して, 粗度 に作用する流体力の X, Y成分を測定した，座標系およ び粗度の設置角度 $\theta$ の定義を後述の記号も含めて図-2 に示す. 粗度は直径 $\mathrm{D}=7.0,10.0,12.0 \mathrm{~cm}$ の球を 4 等 分した形状の $1 / 4$ 球型粗度, 同じく直径 $D=7.0,10.0$, $12.0 \mathrm{~cm}$ の半円筒(高さはD の $1 / 2$ であり, $1 / 4$ 球と同じ 高さ)を非対称構造物として用いた. 比較のために対称構 造物として $D=10.0 \mathrm{~cm}$ の半球を用いた実験も行っている. また図-1 の左上に示すように水位変動 とを容量式波高 計により測定している. サンプリング周波数 $50 \mathrm{~Hz}$ でデー タを取得し，ゼロアップクロス法により 100 波分を抽出し た. 実験は二つに大別され，一つは対称構造物と非対称 構造物の抵抗特性の違いを調べた実験であり(実験 I ), もう一方は非対称構造物を回転させる実験で, 迎角の違 いによる特性について検討したものである（実験 II）。

実験 I は表-1に示すように, 対称構造物である半球型 粗度と非対称構造物である $1 / 4$ 球型粗度それぞれについ $\tau, \mathrm{R}_{\mathrm{e}}$ 数 $\left\{=\mathrm{U}_{0} \mathrm{D} / v, \mathrm{U}_{0}\right.$ は断面平均流速の最大值, $\nu\left(=0.01 \mathrm{~cm}^{2} / \mathrm{s}\right)$ は水の動粘性係数 $\}$ を固定し, $\mathrm{KC}$ 数 (= $\mathrm{U}_{0} \mathrm{~T} / \mathrm{D}, \mathrm{T}$ はピストンの周期) を 3 種類に変えて行われ た. 表中の $\mathrm{a}$ はピストンの振幅であるが，図-1からわか るように水槽の両サイドと粗度のある中央部では水槽の管 径が異なるため，本研究では実際のピストンおよび波高 計による水位変動の振幅を $4 / 3$ 倍している. なお, この 時の非対称構造物の設置角度は $\theta=0^{\circ}$ および $180^{\circ}$ で あり，投影面積は半球と $1 / 4$ 球で一致する.

実験 II は表-2に示す 20 ケースについて，主流方向 $(\mathrm{X}$ 方向)に対する粗度の迎角 $\theta$ を $10^{\circ}$ ずつ傾け， $0^{\circ}$ から $180^{\circ}$ まで，また $270^{\circ}$ の場合の計 $20 \times 20=400$ 条件に ついて行われた.

片側のみ駆動するピストン式の振動流では, 対称構造 物を設置した場合でも流速波形に若干の非対称性が生じ る. 本研究では実験 I の条件以外にも対称構造物を用 いた予備実験を行い, 流れの非対称性が小さくなる条件 を選定して実験を行っている. しかし厳密に対称とはいえ ない為, $\theta$ が $0^{\circ}$ から $90^{\circ}$ までの結果と対応する $180^{\circ}$ から $90^{\circ}$ までの結果を適宜平均することで, この問題の 解決を図っている $\left(\theta=270^{\circ}\right.$ は $90^{\circ}$ に対応する). 


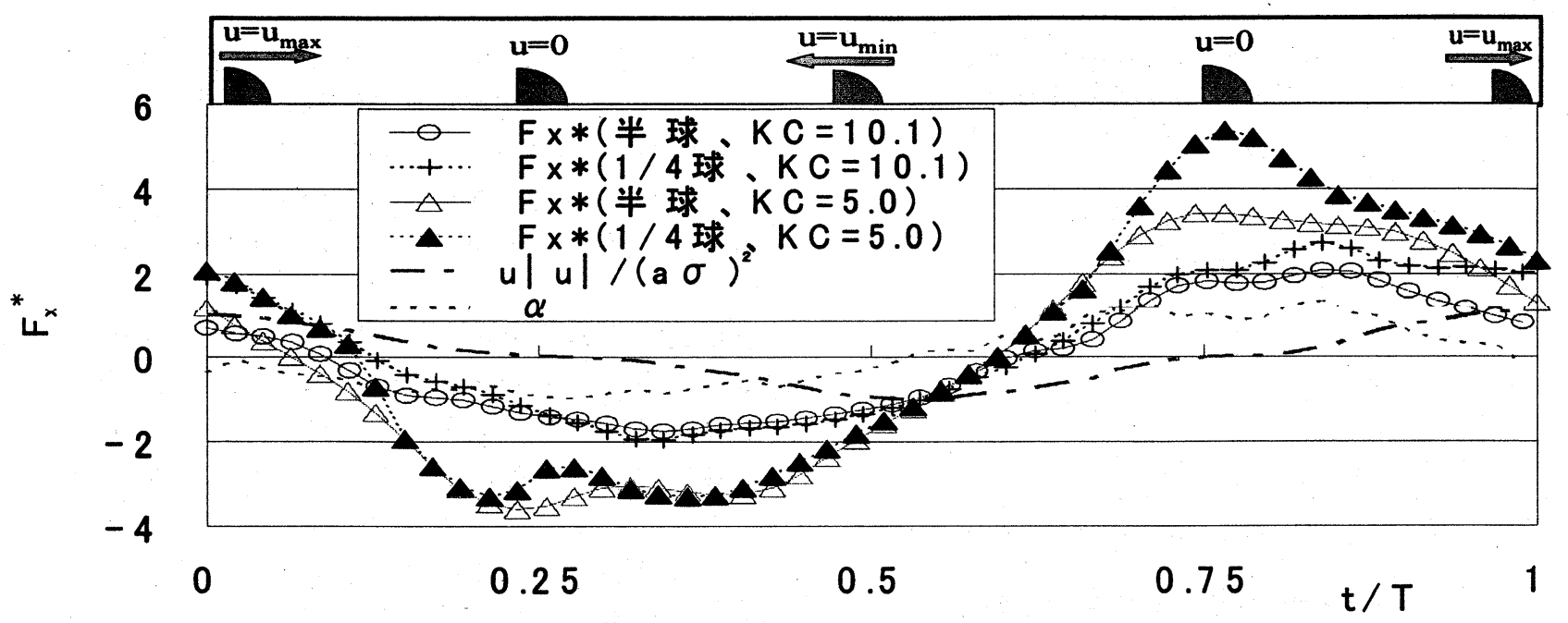

図-3 無次元化された抗力の位相平均波形

\section{3. 結果および考察}

本論文では, 円筒や球等の対称構造物に作用する波 力の議論で頻繁に用いられるモリンン式4),5)が, 非対 称構造物を用いた本実験においても準用できるものと し, 例えば主流方向に対して線型化した式 (1) を仮 定する.

$$
F_{x}=\int_{A x}(1 / 2) C_{D} \rho u|u| d A_{X}+\int_{V} C_{M} \rho(\partial u / \partial t) d V
$$

ここで第 1 項が定常成分の寄与を示す抗力項, 第 2 項 が慣性項であり, $\mathrm{u}$ はX方向の流速, $\mathrm{C}_{\mathrm{D}}$ は抗力係数, $\mathrm{C}_{\mathrm{w}}$ は慣性係数, $A_{x}\left\{=A_{x}(\theta)\right\}$ は粗度のX方向の投影面積, $\mathrm{V}$ は粗度の体積である. $\mathrm{C}_{\mathrm{D}}, \mathrm{C}_{\mathrm{u}}$ は本来 $\mathrm{R}$ 数および $\mathrm{KC}$ 数 の関数と考えられる4)が, 本研究の実験条件内では $\mathrm{R}_{\mathrm{e}}$ 数, $\mathrm{KC}$ 数の変化に対して $\mathrm{C}_{\mathrm{D}}, \mathrm{C}_{\mathrm{H}}$ の変化は小さいものと する. 便宜上主流方向 (X方向)の一周期平均的な抵抗 力を残差抗力, 横断方向 (Y方向) の一周期平均的な力 を残差場力,それらを合成したものを残差合力と呼ぶ こととする. また今後は, 力は全て $\rho \mathrm{A}_{0} \mathrm{U}_{0}{ }^{2} / 2\left(\mathrm{~A}_{0}\right.$ は $\theta=0^{\circ}$ の時の粗度の $X$ 方向の投影面積, $\rho$ は水の密 度で $\left.1 \mathrm{~g} / \mathrm{cm}^{3}\right)$ で無次元化して表記し，上ツキ*を付記し て示す.

\section{（1)対称構造物との比較検討 (実験 I )}

まず対称構造物との比較を通して, 非対称構造 物の抵抗特性を検討した. $1 / 4$ 球と半球に関して,

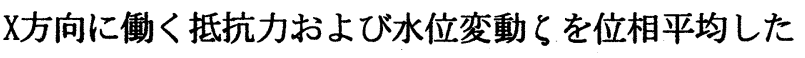
1波長の例を無次元化して図-3に示す. 図の横軸は無 次元時間 $t / T$ であり ( $t$ は実時間), 縦軸は抵抗力 $F_{x}{ }^{*}$ である. また図中には, 式 (1) における抗力の位相 を示す $\mathrm{u}|\mathrm{u}| /(\mathrm{a} \quad \sigma)^{2}$, および慣性力の位相を示す無 次元加速度 $\alpha\left(=\partial \mathrm{u} / \partial \mathrm{t} / \mathrm{a} \sigma^{2}\right)$ を併記している( $\sigma$ は 角振動数). uおよび $\alpha$ は $\zeta$ を時間差分して求めた. 式 （1）を仮定するにあたり u は本来は局所的な値となるべき であるが，ここでは $\mathrm{u} ， \alpha$ は断面平均値を用いた. 抗力 と慣性力の位相を押えるだけなので代用可能とした. ま

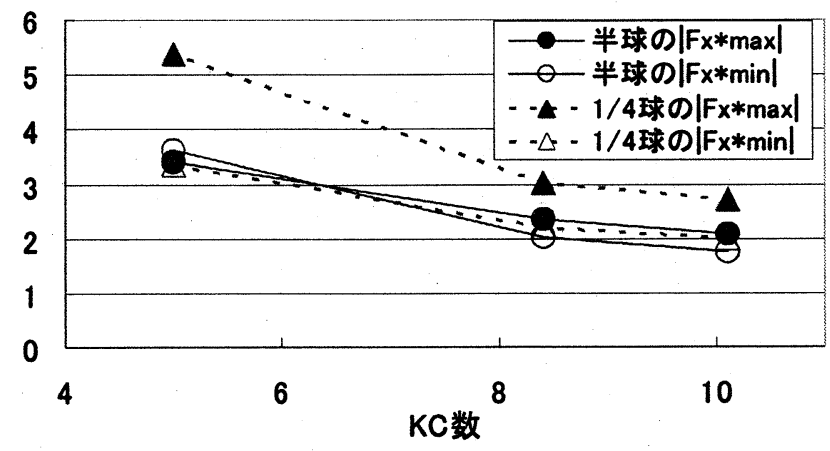

図 -4 抗力の代表值とKC数の関係(実験 I)

た, 図-3の上部に各時間における $1 / 4$ 球型粗度とuの 関係を図示している.

全体的に $\mathrm{F}_{\mathrm{x}}^{*}$ の大きさを比較すると, $\mathrm{KC}$ 数が小さい $\mathrm{KC}=5.0$ の場合の方が, $\mathrm{KC}$ 数が大きい $\mathrm{KC}=10.1$ に比較 して值が大きくなっており, 式 (1) から予想されるように 慣性力が大きく寄与していることが分かる． 位相を概 観すると, 同一KC数における対称構造物と非対称構造 物の間に抵抗力の位相の差はほとんど無いが, KC数が 大きい場合のほうが小さい場合と比べて位相が若干遅 れ, $\mathrm{u}|\mathrm{u}| /(\mathrm{a} \sigma)^{2}$ の位相に近づいていることが分か る. これも式 (1) から想定されるように, KC数が大 きくなったために相対的に抗力が卓越したため,その 位相に近づいたと考えることが出来よう.次に一周期 間における半球と $1 / 4$ 球の $\mathrm{F}_{\mathrm{x}}^{*}$ の挙動をみると, 同じ $\mathrm{KC}$ 数では $\mathrm{t} / \mathrm{T}=0.15 \sim 0.7$ においてそれらの曲線はほ ぼ一致している. KC 数が大きい $\mathrm{KC}=10.1$ では, 対称 と非対称で大きく $\mathrm{F}_{\mathrm{x}}{ }^{*}$ が異なるのは $\mathrm{t} / \mathrm{T}=1$ (または, 0$)$ の時であり, $\mathrm{u}|\mathrm{u}| /(\mathrm{a} \sigma)^{2}$ が最大になる位相と一致 していることから,抗力が強く影響していることが分 かる. 逆にKC数が小さいKC=5.0では, 対称と非対称 で大きく $\mathrm{F}_{\mathrm{x}}{ }^{*}$ が異なるのは $\mathrm{t} / \mathrm{T}=0.75$ の時であり， $\alpha$ が 最大になる位相であることから慣性力が大きく寄与してい ると思われる.この時の $\mathrm{F}_{\mathrm{x}}{ }^{*}$ は流速が0であり，また慣 性力の大きさに関係すると考えられる構造物の体 積が対称構造物に比べて半分にすぎないのに，とく に急激な増加を示しており興味深い。但し図から分か 

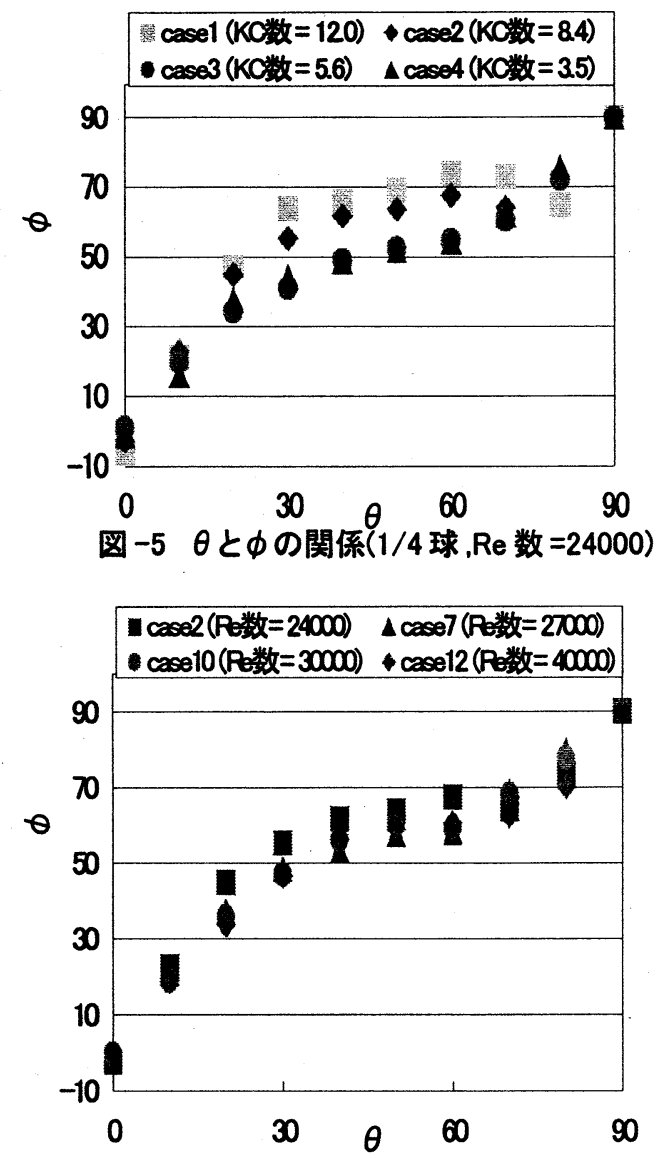

図-6 $\theta$ とめの関係(1/4 球,KC 数 $=8.4)$
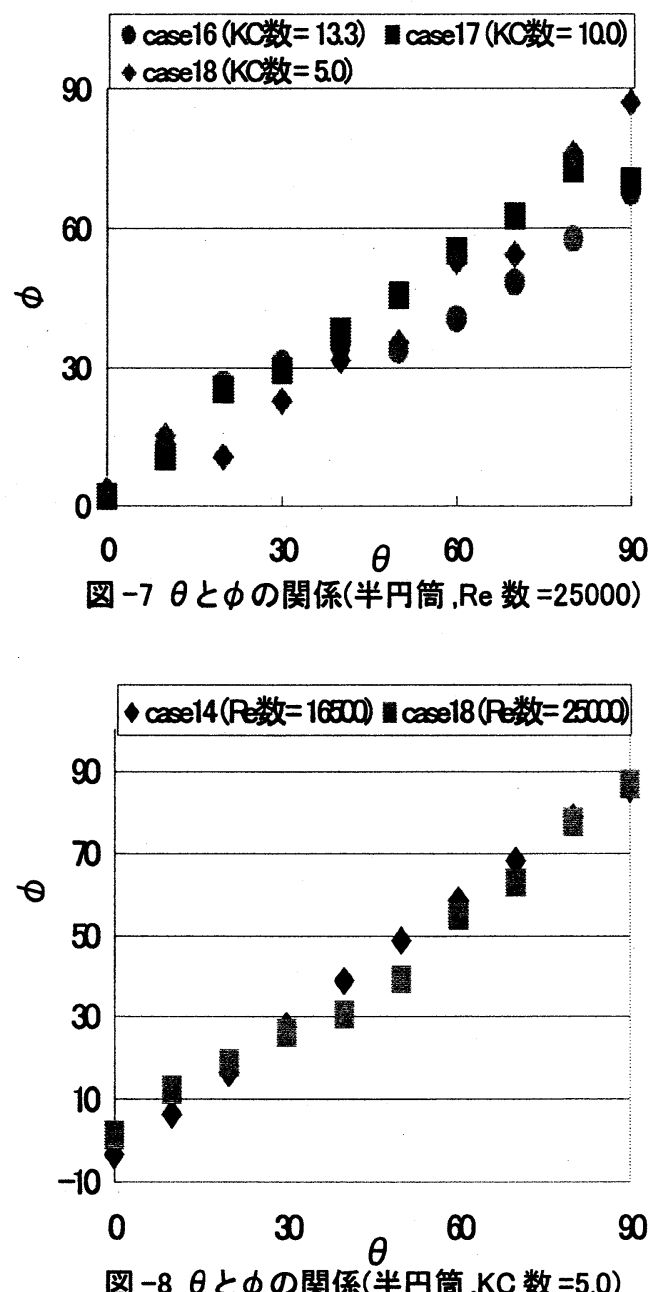

るように, どちらの $\mathrm{KC}$ 数でも $\mathrm{t} / \mathrm{T}=0 \sim 0.15$ および $0.7 \sim 1$ で $1 / 4$ 球型粗度の $\mathrm{F}_{\mathrm{x}}^{*}$ は半球型粗度に比べて 増加しており,構造物の非対称性によって抗力, 慣性 力ともに増加する.結果的にはこの時間帯における力 の増加分により,一周期平均值である残差抗力が発生 している.

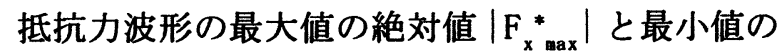
絶対値 $\left|\mathrm{F}_{x \text { min }}^{*}\right|$ を抵抗力の代表值として求めると (図 -4), $\left|\mathrm{F}_{x \text { (in }}^{*}\right|$ は KC 数に関わらず $1 / 4$ 球型粗度 と半球型粗度で一致しているが, $\left|\mathrm{F}_{x \text { max }}^{*}\right|$ は KC 数の 減少とともに $1 / 4$ 球型粗度の方が大きくなってい る.これは図 -3 から分かるように, $t / \mathrm{T}=0.75$ 付近 で構造物の非対称性によって慣性力が大きくなっ たことに因る. 図 -4 から粗度の非対称性に関わら ず KC 数の増加に伴い $\left|\mathrm{F}_{\mathrm{x} \text { min }}^{*}\right|$ および $\left|\mathrm{F}_{\mathrm{x} \text { max }}^{*}\right|$ は减少 し，一定に近づく傾向が同える．対称構造物では KC 数が大きくなると抗力振幅は一定になることが 明らかとなっており ${ }^{5)}$, 同様の理由と考えられる.

\section{(2)非対称構造物の方向抵抗特性 (実験 II)}

1/4球型粗度と半円筒型粗度それぞれを主流に対し て傾けて設置することで,迎角の変化に伴う非対称構 造物の残差抵抗特性を調べた. $\mathrm{X}, \mathrm{Y}$ 二方向の力の時系 列を一周期平均することで各方向の残差抗力 $\mathrm{f}_{\mathrm{x}}{ }^{*}$, 残 差揚力 $\mathrm{f}_{\mathrm{y}}^{*}$, 更にそれらを合成することで残差合力 $\mathrm{f}^{*}$ を算定した. また $\mathrm{f}_{\mathrm{x}}^{*}, \mathrm{f}_{\mathrm{y}}^{*}$ より残差合力の働く角度 $\phi$ を算定した.

迎角 $\theta$ の変化に伴う $\phi$ の応答の例を図 $-5 \sim 8$ に 示す. $1 / 4$ 球型粗度において $\mathrm{R}_{\mathrm{e}}$ 数を固定して $\mathrm{KC}$ 数 をパラメータとした図-5では, KC数が大きくなると фが増加しており, 若干のKC数依存性が認められた. しかし, KC数を固定した図-6からは, $\mathrm{R}_{\mathrm{e}}$ 数への依存 性は殆どみられなかった. 半円筒についてはKC数依 存性を調べた図-7, $\mathrm{R}_{\mathrm{e}}$ 数依存性を調べた図-8から分 かるように, 明確な依存性はともに認められなかっ た.これより，いずれの条件においても $\theta$ の増加に 伴って $\phi$ は単調に増加しており, 周期の短い往復流場 においても非対称構造物の設置角度を変えることによ り，任意の方向に残差合力を生成可能であることが分 かった.

横軸に迎角 $\theta$ ，縦軸を a) 残差合力 $\mathrm{f}^{*}$, b) 残差抗力 $\mathrm{f}_{\mathrm{x}}^{*}, \mathrm{c}$ ) 残差揚力 $\mathrm{f}_{\mathrm{y}}{ }^{*}$ とし, $\mathrm{KC}$ 数をパラメータにして 1/4球, 半円筒についての結果をそれぞれ図-9, 10に 示す.各縦軸の力に及ぼす投影面積の影響を評価する ため，参考として図中には実線で a)，b)，c）それぞ れに $A_{x} / A_{0}, A_{x} / A_{0}, A_{y} / A_{0}$ を併記している. 但し, $A_{y}(\theta)$ はY方向の投影面積である.またこれらの面積比の值 は図の左側の縦軸に順応しているが, 実際には $\theta=0$ において $A_{x} / A_{0}=1, A_{y} / A_{0}=0.5$ であり, $\theta=90^{\circ}$ では $A_{x} / A_{0}=0.5, A_{y} / A_{0}=1$ である. 


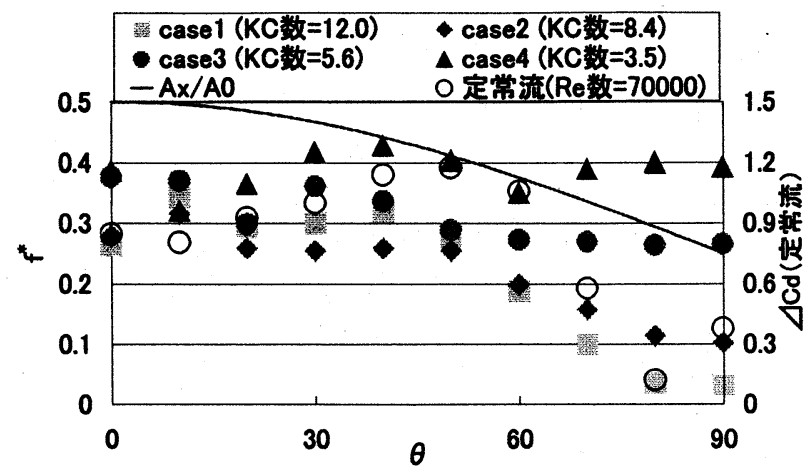

a) 残差合力

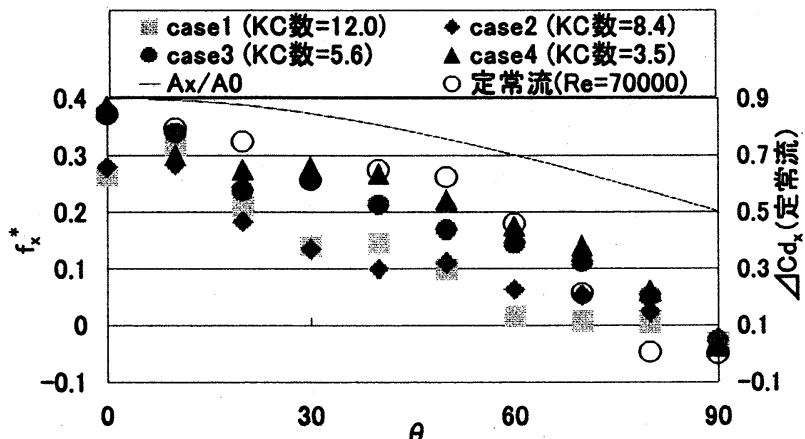

b) X方向残差抗力

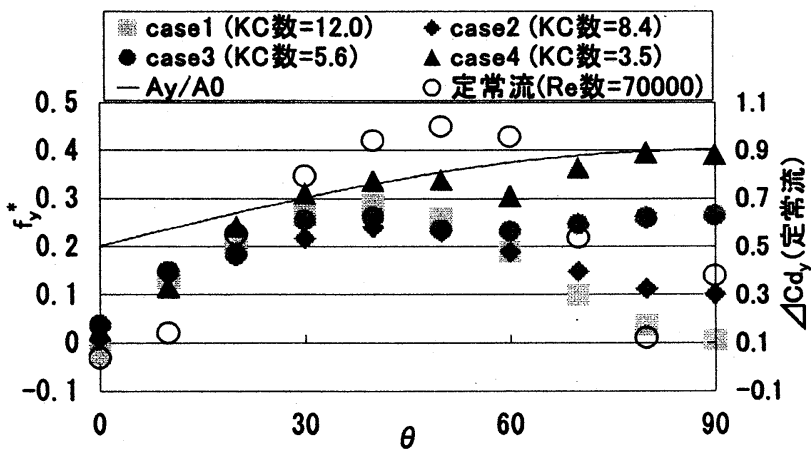

c) y方向残差揚力

図-9 1/4 球型粗度の残差抵抗特性 $(\operatorname{Re}$ 数 $=24000)$

図-9a)から分かるように, 1/4球型粗度の残差合力 $\mathrm{f}^{*}$ はKC数が小さい場合 $\theta$ に関わらずほぼ一定である が, KC数の増加に伴いf* $\mathrm{f}^{*}$ は減少しており, その傾向は $\theta$ が大きいところで顕著である.これは成分ごとに示 した図-9b),c)から明らかなように，図-9c)でKC数が 大きい場合に, $\theta$ が $0 \sim 40^{\circ}$ 程度までは $\theta$ の増加に伴 い残差揚力 $\mathrm{f}_{\mathrm{y}}{ }^{*}$ が増加するのに対し, $50^{\circ}$ 以上になる と逆に $\theta$ の増加に対してf ${ }_{\mathrm{y}}^{*}$ が減少することに起因し ている.これより $\theta$ が大きいときには, KC数に応じて 慣性残差揚力は働くが定常残差揚力(ここではY方向 モリソン式の抗力項に起因寸る力のこと)は殆ど働か

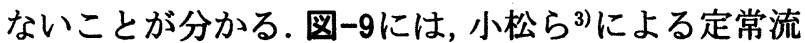
場で1/4球型粗度を回転させて残差抵抗力を評価した 実験結果も併記している.KC数が十分大きい場合に相 当する定常流場においても同様な結果となっており, この結果からも定常残差揚力が小さいことが伺える. 投影面積 $A_{\mathrm{y}}$ は $\theta$ が $0 \sim 90^{\circ}$ まで単調に増加するため, $\theta$ の増加に伴う $f_{y}^{*}$ の減少は特筆すべき点である. $f_{x}^{*}$ は $\theta$ の増加に伴い単調に減少するが, その変化率は投

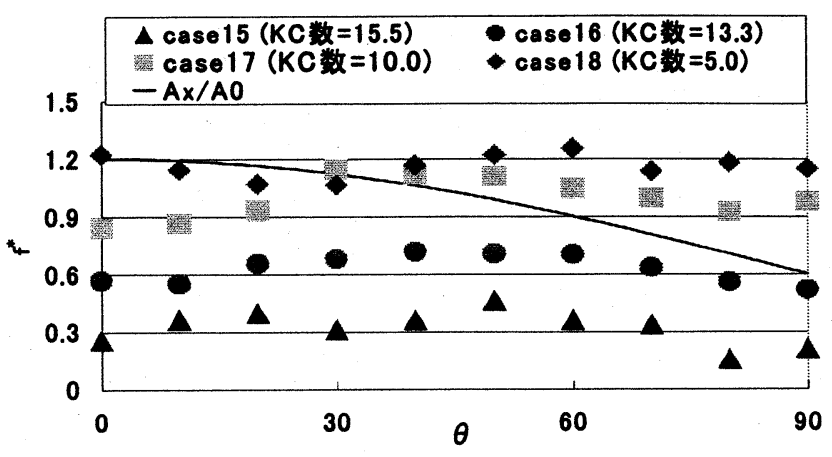

a) 残差合力

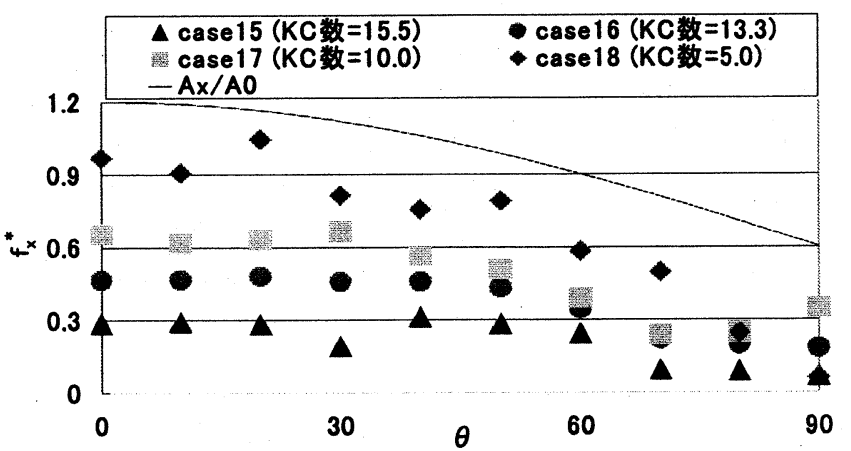

b) $X$ 方向残差抗力

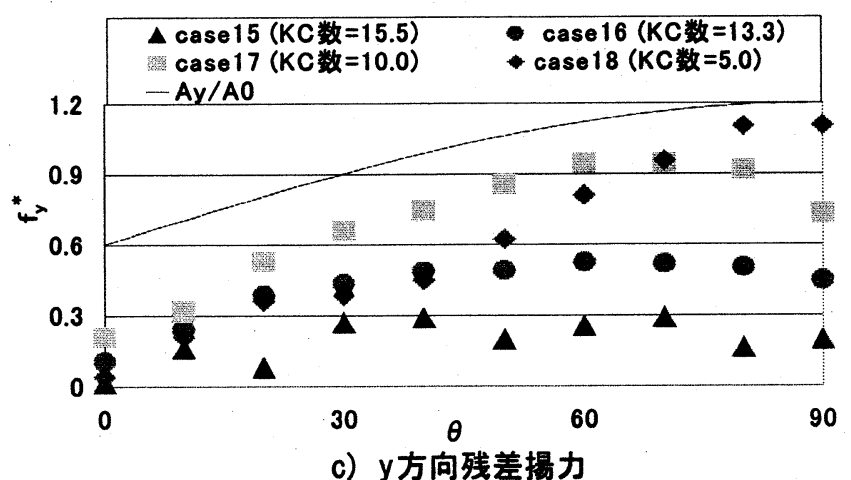

図-10 半円筒型粗度の残差抵抗特性 $(\operatorname{Re}$ 数 $=25000)$

影面積の減少より若干大きくなっておりそれ以外の効 果も寄与している.いずれの $\theta$ においてもKC数の増加 に伴い $\mathrm{f}_{\mathrm{x}}^{*}$ はほぼ减少しているが, これは主流方向の慣 性力が小さくなるためである.

半円筒では, 図-10a)から分かるようにKC数の増加 に伴いf*は减少するものの, $\theta$ の変化に関わらずほぼ 一定であった．成分ごとにみると，図-10b)から $\mathrm{f}_{\mathrm{x}}^{*}$ は $\theta$ の増加に伴い単調に減少し, 逆に $\mathrm{f}_{\mathrm{y}}{ }^{*}$ は図-10c)に示 された様にほぼ単調増加である.投影面積の変化と定 性的には同じ傾向であるが, 投影面積の変化よりもKC 数の変化,即ち慣性力の影響の方が大きい.

図 -9 と図 -10 の $\mathrm{R}_{\mathrm{e}}$ 数, $\mathrm{KC}$ 数は同程度であることか ら, 両図における類似した条件の結果を比較すると, $1 / 4$ 球型よりも半円筒型の方が $\mathrm{f}^{*}, \mathrm{f}_{\mathrm{x}}{ }^{*}, \mathrm{f}_{\mathrm{y}}{ }^{*}$ 全て大きく, BaNK 工法に用いる構造物としては有利なことが分か る.これは球体の代表スケールとして直径をとると実 質的な代表スケールを過大評価することによる.つま り $1 / 4$ 球と半円筒で代表長さと定義した直径 D は半 円筒では高さ方向に一定であるが, $1 / 4$ 球型では高 


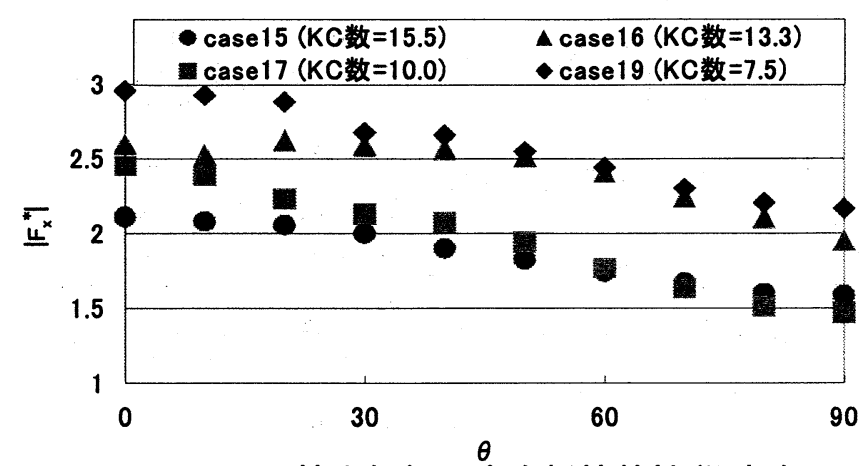

図-11 抗力振幅の方向抵抗特性 ( $X$ 方向)

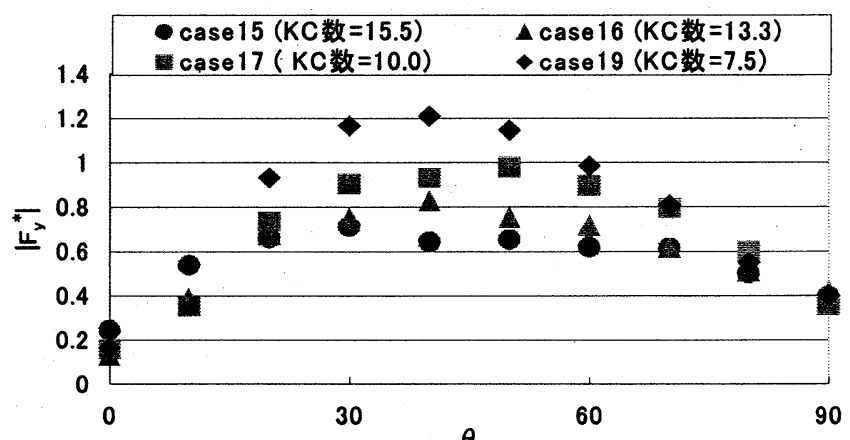

図-12 抗力振幅の方向抵抗特性 ( $Y$ 方向)

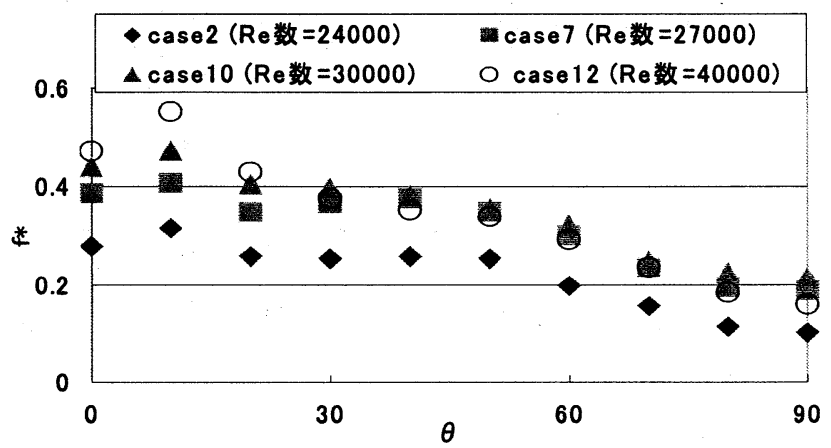

図 -13 $1 / 4$ 球型粗度の残差合力の $R e$ 数依存性 $(K C$ 数 $=8.4)$

さ方向に減少していくためである.このように考える と，1/4球の実質的な KC 数は現在の定義より大きい ことになる. 全ての実験条件における半円筒の特性 が, $1 / 4$ 球の KC 数が小さい場合 $(K C$ 数 $=3.5)$ と同様 な傾向を示したのはこのような理由によると考えられ る.

成分毎の抵抗力の代表値として,各方向の最大值と 最小值から求めた平均振幅 $\left|\mathrm{F}_{\mathrm{x}}{ }^{*}\right|=\left(\left|\mathrm{F}_{\mathrm{x} \text { max }}{ }^{*}\right|+\left|\mathrm{F}_{\mathrm{x} \text { min }}{ }^{*}\right|\right) /$ 2 , および $\left|\mathrm{F}_{\mathrm{y}}{ }^{*}\right|=\left(\left|\mathrm{F}_{\mathrm{y} \text { max }}{ }^{*}\right|+\left|\mathrm{F}_{\mathrm{y} \text { min }}^{*}\right|\right) / 2$ の迎角依存性を 半円筒に関してそれぞれ図-11，12に示す。これより 半円筒の抵抗力の振幅は, KC数が大きい場合の $1 / 4$ 球 型粗度の残差抵抗特性と類似しているが,この点は今 後の課題である.全体的に振動方向の振幅の方が大き $<, \theta=0^{\circ}$ の抵抗力の振幅は, $\theta=90^{\circ}$ の際の揚力振 幅より5倍程度大きい. 先述のように半円筒型粗度お よび $1 / 4$ 球型粗度でKC数が小さい場合には, $\theta=0^{\circ}$

における $\mathrm{f}_{\mathrm{x}}{ }^{*}$ と $\theta=90^{\circ}$ のときの $\mathrm{f}_{\mathrm{y}}{ }^{*}$ が同程度であ る. 振幅は非等方的であるのに対し，一周期平均 でみると等方的となることは興味深い.
最後に残差抵抗力の方向特性に対する $\mathrm{R}$ 数の効果を 示す例として, 横軸に $\theta$, 縦軸を $\mathrm{f}^{*}$ とし, $\mathrm{R}_{\mathrm{e}}$ 数をパラ メータとした $1 / 4$ 球型粗度の結果を図-13に示す. 今 回の実験条件内ではR 数が変化しても $\mathrm{f}^{*} の$ 方向特性は 殆ど変化しておらず, 大きさのみに影響しており, $\mathrm{R}_{\mathrm{e}}$ 数の増加によって残差合力は若干増加している.

\section{4. 結論}

周期の短い往復流場における非対称構造物の抵抗特性 を把握するための実験を行い，以下の知見を得た.

1）構造物形状の非対称性によって残差抗力が生じるこ とが明らかとなった， $1 / 4$ 球型粗度では，加速度が 大きくなる位相から流速が大きくなる位相までの抵 抗力の増加によって残差抗力が発生する.

2） $1 / 4$ 球型粗度および半円筒型粗度を主流方向に対 して傾けて設置することによって任意の方向に残差 合力が生成可能である. 従って, 任意の方向に波 浪残差流が生成可能となることが期待される.

3） $1 / 4$ 球型粗度で KC 数が大きい場合, 迎角 $\theta$ が 50 〜 $90^{\circ}$ の範囲では $\theta$ の増加に伴い残差揚力が減 少する. また，それに伴い残差合力も减少する.

4）波浪場のように KC 数が小さい場合, 残差合力が迎 角に殁ど影響されずに生じるため，BaNKシステム において著しい残差流の偏流効果が期待される.

謝辞: 本研究を行うにあたり,九州大学大学院工学研究院技 術専門官の藤田和夫氏に実験装置の製作において多 大なる援助をいただいた.また, 本研究の一部はNEDO の平成13年度産業技術研究助成事業のもとに行われ た.ここに記して哚甚なる謝意を表します。

\section{参考文献}

1）小松利光, 齊田倫範, 小橋乃子, 安達貴浩, 柴田卓 也:方向抵抗特性をもつ海底小規模構造物を用いた海 底近傍の物質輸送の制御, 水工学論文集, 第 45 巻, pp.1087-1092, 2001

2）小松利光, 柴田卓也, 押川英夫, 柴多哲郎, 安達貴 浩, 小橋乃子, 櫨田操 : BaNKシステムの底質輸送制 御効果に関する研究, 水工学論文集, 第 46 巻, pp.457-462, 2002

3）小松利光, 小橋乃子, 和田真人, 藤田和夫, 矢野真 一郎, 安達貴浩 : 任意の方向に潮汐残差流を創造す るための偏流型粗度の開発，水工学論文集，第 43 巻, pp.833-838, 1999

4) 岩垣雄一 : 最新 海岸工学, 森北出版,pp.61-66, 1987

5）岩田好一朗,水谷法美: 没水球体に作用する波力の 特性に関する研究,土木学会論文集,第 405 号 / II 11,pp.215-224, 1989

(2002. 9. 30受付) 